\title{
INVESTING ON THE POLISH MARKET OF CONDO-HOTELS AND APART-HOTELS - SELECTED LEGAL ISSUES
}

\author{
Ewelina Badura*
}

\begin{abstract}
The institutions of a condo-hotel and apart-hotel are not defined in Polish legislation. However, ownership issues of such facilities are not entirely outside statutory regulations. Legal diversity, the absence of an unambiguous definition and of transparent statistical data, combined with the interchangeable use of the terms "condo-hotel" and "apart-hotel" by investors and operators of such facilities may raise concerns about the proper functioning of the market for this type of investment in Poland. The risks of investing in condo-hotels and apart-hotels in Poland can be divided into several basic categories.
\end{abstract}

Keywords: rental, real property, condo-hotel, apart-hotel, risk

\section{INTRODUCTION}

Investing in real property is a popular form of investment in Poland, which is partly a result of low interest rates on bank deposits and the last crisis, which discouraged many investors from playing on the stock exchange $^{1}$. In February 2020 neither property buyers nor lessors could predict

Dr. Ewelina Badura, Assistant Professor, Institutes of Law, College of Economics, Finance and Law, Department of Real Estate and Tax Law, Cracow University of Economics; correspondence address: ul. Rakowicka 27, 31-510 Kraków, Poland; e-mail: badurae@uek. krakow.pl; https://orcid.org/ 0000-0002-5514-6299.

1 Anders Åslund, The Last Shall Be the First: The East European Financial Crisis (Washington, Dc: Peterson Institute for International Economics, 2010), 53-55. 
the Coronavirus pandemic. In many countries, including Poland, the operations of hotels and other short-term rental facilities were suspended for several months. It may be expected that this situation will significantly affect the developing short-term rental market ${ }^{2}$.

Polish residential rental market is relatively under-developed compared to other countries of the European Union. Like in other Member-States from the so-called Eastern Block, the residential market is dominated by owner-occupancy with a relatively underdeveloped rental market, which hampers migrations from poorer regions to fast - developing cities.

Strong emphasis on property ownership, as opposed to renting, also limits the mobility of workers and makes it difficult for young people to find housing. At the end of 2018 and at the beginning of 2019 approximately $84.2 \%$ of the population in Poland lived in their own property (compared to the total number of dwellings in a given area). In Germany, for example, the owner-occupancy rate was $51.5 \%$. The situation is a result of the legal status of the rental market, which in Poland is poorly regulated and as such does not offer a good alternative to ownership.

On the other hand, short-term rental has become very popular in recent years. Portals offering booking services such as Booking or Airbnb allow their users to find accommodation not only in conventional hotels, inns or $\mathrm{B} \& \mathrm{Bs}$, but also in attractively located private apartments. We can observe the growing popularity of condo-hotels, where individual rooms for rent belonging to different owners are managed by the so called property manager. The majority of condo-hotels and holiday apartments are located at seaside and mountain towns ${ }^{3}$.

The primary aim of this article is to identify potential risks related to investing in the Polish market of short-term rentals. Furthermore, the article presents arguments in favor of following the example of other countries that have introduced legal regulations in this area ${ }^{4}$. In order to come up

2 April 8, 2020 https://ec.europa.eu/eurostat/documents/2995521/10294612/ 2-08042020-AP-EN.pdf/d624aabc-eca8-029c-868b-f80efec5b89a.

3 Ira Gary Peppercorn and Claude Taffin, Rental Housing. Lessons from International Experience and Policies for Emerging Markets (Washington Dc: The World Bank, 2013), 109-115.

4 See for instance European Commission; "A European agenda for the collaborative economy," COM (2016) 184 final. 
with an appropriate policy concerning short-term rental the authorities at the local level should have the powers to adopt legal regulations that meet local social and economic needs of their communities ${ }^{5}$. The desired solutions should ensure the protection of public interest while safeguarding freedoms and safety of the residents.

\section{THE SOURCES OF THE CONDO AND APARTMENT SYSTEMS}

In the condo-hotel system an investor purchases an apartment in a hotel building and concludes with a developer a lease agreement for it, on the basis of which the owner of the apartment derives income. Such projects are usually developed by large companies specializing in the hotel industry. A developer, as opposed to a traditional hotel operator, does not become the owner of the entire property, but sells separate apartments. In the next step the property developer leases the apartments from the owners and, taking advantage of its own infrastructure such as restaurants, spa and wellness, which operate in the building, runs a hotel.

The condo-hotel system, as a form of ownership of residential premises was well-known in ancient Egypt and Greece, where it was addressed to those who could not afford their own apartment ${ }^{6}$. In Western Europe it became popular after the Second World War, as a response to the increased demand for housing and the need for solutions more economical than ownership. The most dynamic development of condominiums took place in the United States ${ }^{7}$, where it represents a valid alternative to a prevailing model in which the entire building has a single owner ${ }^{8}$. The condominium model is a combination of two rights. The first right is the right to separate ownership of the part of the building and the other is the right to

5 Dianne Dredge, "The impact of regulatory approaches targeting collaborative economy in the tourism accommodation sector," Impulse paper, no. 9 Aalborg University (2016): 3, 24.

6 George M. Armstrong jr., "Louisiana Condominium Law and the Civilian Tradition," Louisiana Law Review 46, no. 1 (1985): 71-72.

7 Robyn Taylor, "Why Condo Hotels are a Hot Concept," National Real Estate Investor (2005): 89.

8 Karolina Chrabąszcz, "Condoinvestments as an alternative form of capital allocation," Scientific Papers of the Matopolska University of Economics in Tarnów 24, no. 1 (2014): 49. 
co-ownership of common areas (such as corridors, staircases, lifts, the roof, and the area surrounding the property).

There are two most common legal regimes concerning condominiums in Europe 9 . Under the first regime, the owner acquires two separate, but directly related rights. The first one is the right to ownership of the premises and the other one is the right to co-ownership of the common areas. Such regulations exist in Belgium, Greece, Portugal and Poland. Under the other regime all the owners of the units are also co-owners of the building and the plot and each of them has a special right to the premises (Austria, Holland, Germany and Switzerland). In principle, in both legal regimes common areas are managed by their co-owners ${ }^{10}$. In the apart-hotel model an investor purchases a property and concludes with a developer a lease agreement, deriving income on its basis ${ }^{11}$. This model also pertains to hotels, dining facilities, and spa services, as well as to typical residential buildings with a reception but without a restaurant or recreational facilities.

Condo-hotels and apart-hotels first appeared in Mediterranean countries, and then spread to other parts of the continent. These systems as alternative investment methods have been popular on the international market for over 20 years. Condo-hotels and apart-hotels are based on the concept of concluding two agreements: a property purchase agreement and a property lease agreement. However, these systems differ from one another" ${ }^{12}$. The "condo" system describes ownership issues, and the "apartment" system deals with functional issues, therefore additional subcatego-

9 Real Property Law and Procedure in the European Union, General Report, European University Institute (EUI) Florence/European Private Law Forum Deutsches Notarinstitut (DNotI) Würzburg, 2005, https:/www.eui.eu/Documents/DepartmentsCentres/ Law/ResearchTeaching/ResearchThemes/EuropeanPrivateLaw/RealPropertyProject/GeneralReport.pdf.

10 Cornelius Van Der Merwe, European Condominium Law (Cambridge: Cambridge University Press, 2015), 9 et al.

11 James F. Downey, "The Aparthotel: A Useful Tool for Investors and Developers," Cornell Hotel and Restaurant Administration Quarterly, no. 32 (1991): 53-55.

12 The difference between condo-hotels and apart-hotels concerns, among others, property management. Rooms in condo hotels are usually managed by the developer. On the other hand, apartments in apart-hotels are usually not managed by a developer, but by a specialized external company. The difference between these systems also relates to costs. 
ries of products such as: condo-apartments and condo-hotels can also be distinguished on the Polish market.

\subsection{Development of condo and apartment systems in Poland}

In Poland the equivalent of condominiums are housing communities, however, the article focuses on apart-hotels, as well as condo-hotels. They have emerged as a result of transferring the condo model to the hotel market and are treated as a combination of an investment and "secondary residence". In Poland, the development of condo-hotels and apart-hotels have so far been concentrated mainly in tourist destinations such as Gdańsk, Sopot and Zakopane. However, there may be more such apartments outside large cities as well ${ }^{13}$. It is important to distinguish the two basic real estate markets: the investment market, which includes the transfer of ownership rights and related rights and the rental market, which relates to the conclusion of agreements setting out mutual rights and obligations relating to the use of another's unit. Although the condo-hotels and apart-hotels markets are relatively young they are in a phase of rapid development.

First mention of condo-hotels and apart-hotels appeared on the Polish real estate just as it started to develop, at beginning of the 1990s. However, these options did not meet with interest of potential investors. It was mainly due to the fact that the tourist sector was in its infancy in Poland and property was largely seen as means to satisfy the basic need related to housing. Few people recognized the opportunity to derive profits from such an investment. Another factor that hampered the development of condo-hotels and apart-hotels in Poland was the fact that they were associated with the concept of time - sharing, which was not legally regulated in Poland until the introduction of the Act on timeshares in $2011^{14}$. Still, in the Polish legal system timeshare refers to services related to holiday stays

13 Report: Hotel and condo hotel market in Poland, Emmerson Evaluation 2020: https://www.emmerson-evaluation.pl/wp-content/uploads/2020/04/hotel-and-condo-hotel-market-in-poland-2020-report-pdf.pdf.

14 Timeshare Act of 16 September 2011, Journal of Laws 230.1370. [Ustawa z dnia 16 września 2011 o timeshare, Dz. U. 2011 no. 230 poz. 1370]. 
and property exchange and does not cover the issues related to ownership or the manner of managing property ${ }^{15}$.

\subsection{Short-term rental popularity increase in Poland}

The accession of Poland to the European Union in 2004 led to many changes, also on the real estate market. One of them was the emergence of many medium and long - term investors, accompanied by the accessibility of mortgages, growth in wealth and easier access to capital and industry know-how for property developers ${ }^{16}$. It resulted in a boom on the real estate market in the years 2006-2007. Real property became to be more frequently seen as a source of passive income and a safe investment instrument and purchasing property in popular holiday destinations in Poland as well as in Spain and Croatia became a common practice for investors. Since 2007 the sector has been dynamically developing, particularly in the biggest seaside resorts such as Sopot, Władysławowo, Kołobrzeg, Międzyzdroje, Świnoujście and in popular Mazurian cities such as Mikołajki, Olsztyn, and in the mountainous regions of Southern of Poland such as Zakopane, Wisła, and Karpacz ${ }^{17}$.

The financial crisis of 2008-2009 led to a downturn on the real estate market, including short-term rentals. Investing in condo-hotels and apart-hotels in that period carried a lot of risk. The slowdown on the basic housing market was the main reason for a search for new investment opportunities by developers. Condo-hotels became an alternative investment product. The market of condo-hotels and apart-hotels was not covered by strict legal regulations, unlike the activities of development companies on the residential market, regulated by the Act on Protection of the Rights

15 Kamil Zaradkiewicz, "Timesharing - a special relation of property law," in Private law system, vol. 4, Property law, ed. Edward Gniewek (Warsaw: C.H. Beck, 2012), 167.

16 Hans Joachim Dübel, Władysław Jan Brzeski, and Ellen Hamilton, Rental Choice and Housing Policy Realignment in Transition: Post-Privatization Challenges in the Europe and Central Asia Region, Policy Research Working Paper, World Bank, no. 3884 (2006): 42 et al.

17 Report: Hotel and condo hotel market in Poland, Emmerson Evaluation, 2020, https:/www.emmerson-evaluation.pl/wp-content/uploads/2020/04/hotel-and-condo-hotel-market-in-poland-2020-report-pdf.pdf. 
of Buyers of Residential Units and Single-Family Houses ${ }^{18}$ (the so-called Developers Act). The development of investment in short-term rental was also supported by optimistic assumptions regarding the demand for accommodation in connection with the organization of the Euro 2012 football tournament in Poland and the prospect of high returns on hotel operations in connection with this mass event ${ }^{19}$. The market of condo-hotels and aparthotels continued to grow in the following years.

Until spring 2020, the short-term rental market in Poland was steadily developing ${ }^{20}$. Aparthotels appeared in Poland as early as in the 1980's, with residential buildings that, compared to the prevalent standard in that period, were of relatively high standard. At that time, they could be found mainly at the seaside and in mountain towns. In large Polish cities apart-hotels began to appear at the turn of the twenty-first century and presently they are very popular. The majority of such projects are located in large Polish cities such as Warsaw, Gdansk and Wroclaw. In addition, there are about twice as many new projects in holiday resorts ${ }^{21}$. Many apart-hotels can also be found in Krakow, Poznan, Zakopane and Sopot. Construction projects of condo-hotels and apart-hotels are to a large extent financed from investors contributions or the capital raised by the sale of bonds, as opposed to the money coming from developer's own funds or mortgages.

18 Act of 11 September 2011 on the protection of the rights of buyers of a dwelling or a single-family house, Journal of Laws of 2019, item 1805, as amended. [Ustawa z dnia z dnia 16 września 2011 r. o ochronie praw nabywcy lokalu mieszkalnego lub domu jednorodzinnego, Dz. U. z 2019 r. poz. 1805].

19 The impact of the organization of the UEFA EURO 2012 TM European Football Championship on the Polish economy - summary of research results commissioned by the special purpose vehicle of the Minister of Sport and Tourism [Wpływ organizacji Mistrzostw Europy w piłce nożnej UEFA EURO 2012 TM na polską gospodarkę - podsumowanie wyników badań zleconych przez spółkę celową Ministra Sportu i Turystyki], PL.2012 Sp. z o.o., https://bip.msit.gov.pl/download/2/2360/Zalacznik_2_-_Raport_impact___podsumowanie.pdf and https://www.emmerson-evaluation.pl/wp-content/uploads/2020/04/hotel-and-condo-hotel-market-in-poland-2020-report-pdf.pdf.

20 Report: Hotel and condo hotel market in Poland, Emmerson Evaluation, 2020, https://www.emmerson-evaluation.pl/wp-content/uploads/2020/04/hotel-and-condo-hotel-market-in-poland-2020-report-pdf.pdf.

21 Katarzyna Bucholc-Srogosz, "Condohotels on the Polish real estate market," Scientific Notebooks of the AJD Administration Institute in Czestochowa 2, no. 14 (2016): 241-249. 


\section{SHORT-TERM RENTAL IN EUROPE - REGULATIONS IN SELECTED COUNTRIES}

In many cities in the world the law imposes numerous restrictions on short-term rental. It is often regulated at a local level and the laws between states and even cities within the same state ${ }^{22}$. This is mainly due to the fact that short-term rental is perceived differently by different decision-makers and the regulations take into account different social and economic situations in a given state or city.

\subsection{France}

The Law for a Digital Republic in France ${ }^{23}$ has granted municipalities with the powers to determine the rules and manner of registering shortterm rental in their area ${ }^{24}$. This right can be exercised by the cities with a population of over 20,000 residents, such as Paris ${ }^{25}$. The rules governing short-term rental depend on the category of the apartment. It may be classified as primary residence, the secondary residence (Fr. résidence sécondaire) or a tourist apartment (Fr. meublés de touriste) ${ }^{26}$.

22 World Tourism Organization, New Business Models in the Accommodation Industry - Benchmarking of Rules and Regulations in the Short-term Rental Market, UNWTO, Madrid, 2019.

23 Vide: Loi n ${ }^{\circ}$ 2016-1321 du 7.10.2016 no. 1, www.legifrance.gouv.fr.

24 Rules for short-term rental as well as penalties for non-compliance with shortterm rental limits were introduced in 2018 by ELAN Act, ELAN. Loi n ${ }^{\circ}$ 2018-1021 du 23.11.2018 portant évo- lution du logement, de l'aménagement et du numérique (Loi ELAN), JORF no. 0272, 24.11.2018, no. 1, (The law on the evolution of housing, land management and digital technology - ELAN). This law also defines the new type of short-term rental "mobile rental", www.legifrance.gouv.fr.

25 Study on the assessment of the regulatory aspects affecting the collaborative economy in the tourism accommodation sector in the $28 \mathrm{Member}$ States (580/PP/GRO/IMA/15/15111J) https://op.europa.eu/en/publication-detail/-/publication/ff1e669e-526f11e8-be1d-01aa75ed71a1/language-en/format-PDF/source-70757466.

26 Aneta Kaźmierczyk, "Issues of short-term rental in light of EU and member states regulations," PWPM - Review of International, European and Comparative Law, vol. XVII (2019): 189. 
Under French law the property that is the primary residence for its owner can be designated for short-term rental for the maximum period of 120 days a year, and a fine in the amount of up to 10,000 Euros can be imposed on the owner who exceeds this period. The owner is supposed to live in such a property for the remaining part of the year. Rented apartments are subject to obligatory registration. In the event where the owner fails to live in the apartment for 8 months, the property loses its status of the primary of residence and is classified as the secondary residence, covered by different regulations. In order to register short-term rental it is necessary to obtain permission for converting residential premises into commercial premises ${ }^{27}$. Renting out an apartment classified as a secondary residence without authorization is subject to a fine of up to 50,000 Euros.

\subsection{Spain}

The provisions of the Spanish act Ley de Arrendamientos Urbanos $(\mathrm{LAU})^{28}$ protect the tenants and give the property owners more freedom regarding renting out holiday apartments. Under the provisions of "Ley de Propiedad Horizontal" 29 , the majority of three/fifths of the co-owners of the building may decide to limit or prohibit short-term rentals in their property. Condominium may also impose extra charges on owners renting their apartments to tourists. What is more, since 2019 online booking $\operatorname{sites}^{30}$ such as Airbnb, Homeaway, Booking ${ }^{31}$ to name but a few, are obliged to supply the tax authorities with information about the identity of owners of the apartments, their legal title to the apartment, the identity

27 Ibid., 190.

28 More information: Real Decreto-ley 7/2019, de 1 de marzo, de medidas urgentes en materia de vivienda y alquiler. https://www.boe.es/buscar/doc.php?id=BOE-A-2019-3108.

29 More information: https://www.conceptosjuridicos.com/lph-articulo-3/.

30 OECD (2019), An Introduction to Online Platforms and Their Role in the Digital Transformation, OECD Publishing, Paris https://doi.org/10.1787/53e5f593-en.

31 Miquel-Àngel Garcia-López, Jordi Jofre-Monseny, Rodrigo Martínez Mazza and Mariona Segú, "Do short-term rental platforms affect housing Markets? Evidence from AirBnb in Barcelona," IEB Working Paper no. 2019/05, Institut d'Economia de Barcelona, 2019. http://hdl.handle.net/2445/140501. 
of the tenants, the revenue, contact information, the dates of rent, and even dates and methods of payment.

Barcelona $^{32}$ has adopted a special urban plan PEUAT ("Especial Plan Urbanístico de Alojamientos Turísticos de Barcelona”) ${ }^{33}$, under which the city is divided into four zones. Legal regulations have limited the number of apartments for short-term rental and curbed illegal rent. The municipality imposed many fines on the owners and operators of such apartments. A special plan "Plan Especial de Regulación del Uso de Hospedaje" ${ }^{34}$, was adopted in 2019 also in Madrid. It covers only the units that are rented for over 90 days per year and also provides for the division of the city into four zones.

In 2018 Valencia adopted the Act on Tourism and Hotels ("Ley de Turismo y Hospitalidad") ${ }^{35}$ imposing restrictions on short-term rentals. This regulation imposed many limitations regarding the right to tourist license such as the requirement for the apartment to be located on the ground or first floor. Apartments designated for short-term rental may not be located on the same floor as private residential units and they may not represent more than $50 \%$ of all the apartments in the property. In practice, the only apartments that may be designated for short-term rental are the ones that are located on the ground floor or located over a shop.

32 Study on the assessment of the regulatory aspects affecting the collaborative economy in the tourism accommodation sector in the $28 \mathrm{Member}$ States (580/PP/GRO/IMA/15/15111J) https://op.europa.eu/en/publication-detail/-/publication/74984f87-526a-1 1e8-be1d-01aa75ed71a1/language-en/format-PDF/source-70757488.

33 https://ajuntament.barcelona.cat/pla-allotjaments-turistics/es/.

34 More information: April, 2019 https://transparencia.madrid.es/portales/transparencia/es/Medio-ambiente-y-urbanismo/Urbanismo/Planeamiento-urbanistico/Plan-Especial -de-regulacion-del-uso-de-servicios-terciarios-en-la-clase-de-hospedaje/?vgnextfmt=default\&vgnextoid=b71 cbc8d3c9f4610VgnVCM1000001d4a900aRCRD\&vgnextchannel=eae9508929a56510VgnVCM1000008a4a900aRCRD.

35 Consolidated text: Ley 15/2018, de 7 de junio, de turismo, ocio y hospitalidad de la Comunitat Valenciana. https:/www.boe.es/buscar/pdf/2018/BOE-A-2018-8950-consolidado.pdf. 


\subsection{USA}

Regulations of short-term rentals in the USA vary to a large extend between states ${ }^{36}$. Strict regulations in New York ban short-term rentals of less than 30 days, unless at the same time a long-term tenant or the landlord lives in the apartment. In such a case the owner may not fit any locks as the guests must have free access to all the rooms. In practice it is illegal to even advertise short-term rentals and the violators are subject to a fine of up to 7500 dollars. Single-family houses are excluded from scope of these regulations but there are relatively few of those in New York.

San Francisco was one of the first cities to have introduced regulations on short-term rental. The provisions limit the number of days for which an apartment may be rented out. What is more, the owners have to register business activity in the scope of short-term rental. The city authorities hold a list of all registered landlords, who have to report the status of accommodation every quarter. The entire apartment may be rented only for the maximum period of 90 days per year. Similarly to New York, the owners may rent a spare room for an unlimited period on condition that they occupy the property at the same time ${ }^{37}$.

In Los Angeles property owners may rent their apartment only on condition that they occupy it and violators are subject to a fine. The landlords are obliged to register their activity, pay taxes and keep records. Short-term rent may not exceed the period of more than 120 days a year and high fines are imposed if this limit is exceeded. In Washington DC the regulations on short-term rental are also quite strict. The owners may rent only one house in which they live and they are obliged to register their activity. Those who want to rent the entire property must obtain an additional annotation "for vacation". The maximum number of days for which they can rent out an apartment is 90 days and fines for exceeding this limit are very high ${ }^{38}$.

36 Kelly Barron, Edward Kung, and Davide Proserpio, The Effect of Home-Sharing on House Prices and Rents: Evidence from Airbnb, 2020. Available at SSRN: https://ssrn.com/ abstract $=3006832$.

37 Ibid.

38 Ibid. 


\subsection{Germany}

Under the Act on the Improvement of Tenancy Law German lands $s^{39}$ (Act on the "Improvement of Tenancy Law" ${ }^{30}$ ) may adopt regulations that prohibit the use of residential units for non-residential purposes if there is a shortage of housing stock ${ }^{41}$. In a groundbreaking judgment the Federal Constitutional Court ruled that shortage of housing stock constitutes the grounds for the lands to ban short-term rent on their area ${ }^{42}$.

Under the Gesetz über das Verbot der Zweckentfremdung von Wohnraum ${ }^{43}$ "ZwVbG" ${ }^{44}$ in Berlin residential property may not overused for the purposes of short-term rental. Between 2014 and 2016 short-term rent was banned in Berlin entirely but in 2016 the ban was lifted as non-constitutional ${ }^{45}$. Since 1 May 2016 the ban is limited to renting out entire apartments through booking sites. Only single rooms can be rented out on condition that the rented area does not exceed $50 \%$ of the size of the entire apartment. The landlord has to live in the apartment and have a license to rent out the room. In the case of breach of these regulations the landlord risks eviction or a fine up to 500,000 Euros $^{46}$.

39 Christoph Busch, "Regulating Airbnb in Germany - status quo and future trends," Journal of European Consumer and Market Law, vol. 8, no. 1 (2019): 39 - 41.

40 Gesetz zur Verbesserung des Mietrechts und zur Begrenzung des Mietanstiegssowie zur Regelung von Ingenieur- und Architektenleistungen (Mietrechtsverbesserungsgesetz MRVerbG) of 4.11.1971, Rental Law Improvement Act.

41 Kaźmierczyk, "Issues of short-term rental," 192.

42 More information: http://www.kanzlei-wenderoth.de/app/download/5798903892/ BVerfG+1975+Verfassungsm\%C3\%A4\%C3\%9Figkeit\%2C+Genehmigung.pdf.

43 Study on the assessment of the regulatory aspects affecting the collaborative economy in the tourism accommodation sector in the $28 \mathrm{Member}$ States (580/PP/GRO/IMA/15/15111J) https://op.europa.eu/en/publication-detail/-/publication/47969b0d-526f-1 1e8-be1d-01aa75ed71a1/language-en/format-PDF/source-70757501.

44 Gesetz über das Verbot der Zweckentfremdung von Wohnraum; of 29 November 2013 r. GVBI.2013, 626 "ZwVbG", The law prohibiting the misuse of dwellings. Last amendment of 9.04.2018.

45 Kaźmierczyk, "Issues of short-term rental," 193.

46 Vide: \$4 I 7 ZwVbGO. 


\subsection{Poland}

The institutions of a condo-hotel and apart-hotel are not defined in the Polish legislation. The issue of legal separation of specific premises or hotel units is of key significance for the definition of the condo system. It can hence be concluded that condo-hotels in this respect fall within the definition of self-contained dwelling units or units for other purposes as set out in Article 2 of the Unit Ownership Act ${ }^{47}$. Regarding the apartment-hotels, the provisions of the Polish Civil Code are applicable as far as they refer to ownership or joint ownership of real property ${ }^{48}$.

The status of a hotel as a commercial property comes with legal obligations and restrictions ${ }^{49}$. Although such premises can be freely traded, it is not possible to register for permanent residence in such a property. Moreover, such properties are usually subject to higher real estate taxes and, if applicable, higher fees related to perpetual usufruct.

An important role in separating individual residential premises or hotel units is granted by the legislator to a starosta ${ }^{50}$, who issues a certificate confirming that the premises meet the technical and legal requirements for independent residential units or premises for other purposes ${ }^{51}$. This may be particularly important in the context of the regulation on technical conditions for the buildings and their location such as, inter alia ${ }^{52}$, the minimum floor area of a dwelling unit at $25 \mathrm{~m} 2$. The principle purpose of this amendment was to protect the housing market against the emergence of the so-called "micro-apartments", i.e. apartments with a smaller area than that specified by the $\mathrm{law}^{53}$. At the same time, this regulation,

47 Act of 24 June 1994 on the ownership of premises (i.e. Journal of Laws of 2019, item 737, as amended).

48 Aneta Kaźmierczyk, Common property of premises owners. Legal and substantive issues (Warsaw: C.H. Beck, 2015), 539 + LXIII.

49 Aneta Kaźmierczyk, "Certificate of independence of premises," Rejent, no 1 (2013): 11-38.

50 The head of the second tier of a three tier self government system.

51 Ibid.

52 Regulation on the technical conditions to be met by buildings and their location from April 12, 2002, i.e., Journal of Laws of 2019, item 1065.

53 Under the current regulations in force apartments with the area below 20 square meters are not permissible. For thos reason, sometimes such premises are sold as commercial premises. 
depending on the legal status of the residential premises, may have an impact on the possibility of carrying out condo projects, as these terms are commonly identified with very small residential units. These regulations require investors to exercise due diligence in determining the future use of the property.

The categories of a condo-hotel or an apart-hotel are also absent in Polish official statistics, as they have not been identified in the statistics of the Polish Central Statistical Office (GUS) to date ${ }^{54}$. However, such premises are usually included in the statistics on the construction of residential units or hotels. They are not covered by the provisions defining the conditions for providing hospitality services or by the provisions of law specifying the categorization of hotel facilities ${ }^{55}$, i.e. the Polish Act on Tourist Events and Related Tourist Services ${ }^{56}$ and the Regulation of the Minister of Economy and Labor on hotel facilities and other accommodation facilities ${ }^{57}$. The possible division of condo-hotels into specific categories depends upon meeting the criteria set out in the above regulations, which in practice is very difficult in the case of facilities based on a typical housing scheme.

The investment aspect of the purchase of the shares in a condo-hotel so far has not been regulated in the provisions on the investment on the financial market in Poland. Taking into account the fact that a significant proportion of the investment offers include guarantees of a return rate, this area should attract the interest of institutions responsible for the security of financial transactions. The purchasers in this area are entitled to protection only under the general rules of the Polish Civil Code (contractual and tortious liability). Legal diversity, the absence of an unambiguous definition and of transparent statistical data, combined with the interchangeable use

54 Act of 29 June 1995 on official statistics (i.e. Journal of Laws of 2020, item 443, as amended). https://stat.gov.pl.

55 These hotel facilities include:1) hotels and motels; 2) guesthouses - specify; 3) campsites (camping sites), camping sites; 4) excursion houses; 5) youth hostels; 6) shelters.

56 Act of 24 November 2017 on tourist events and related tourist services (i.e., Journal of Laws of 2019, item 548, as amended).

57 Regulation of the Minister of Economy and Labor of 19 August 2004 on hotel facilities and other facilities in which hotel services are provided (consolidated text: Journal of Laws of 2017, item 2166, as amended). 
of the terms "condo-hotel" and "apart-hotel" by investors and operators of such facilities may raise concerns about the proper functioning of the market for this type of investment in Poland.

\section{SELECTED LEGAL RISKS RELATED TO INVESTING IN CONDO-HOTELS AND APART-HOTELS IN POLAND}

The risks of investing in condo-hotels and apart-hotels in Poland can be divided into several basic categories. The first group concerns financial risk, which increases when the investment is financed only from the purchasers' payments or the sale of bonds ${ }^{58}$. The second group of risks is related to security issues. Investments in commercial premises are not subject to the regulations of the Polish Developer's Act, which requires, inter alia, a contract in the form of a notarial deed and the entry in the land and mortgage register ${ }^{59}$. In the absence of such safeguards, in the event where the construction is not completed, the purchaser may lose the money they had invested. Another category of risks concerns the profitability of such an investment. It frequently transpires that the anticipated large profits are unattainable as developers fail to take into account the costs of property management and maintenance. Another group of risk is related to the lack of transparent terms of cooperation, often involving the lack

58 Communique of the Polish Financial Supervision Authority on alternative investments in real estate. of 25.09.2019. https://www.knf.gov.pl/o_nas/komunikaty?articleId $=67218 \& p \_$id $=18$.

59 Art. 23 [Entry of the buyer's claim resulting from the development contract into the land and mortgage register]

1. The development agreement is the basis for entering the claims referred to in paragraph 1 into the land and mortgage register. 2 .

2. In the land and mortgage register kept for the property on which the development project is to be carried out or carried out, the buyer's claim for the construction of the building, the separation of the dwelling and transfer of ownership of the premises and the rights necessary to use the premises to the buyer or transfer to the buyer shall be disclosed. the buyer of real estate together with a detached house or perpetual usufruct of real estate and ownership of a detached house constituting a separate real estate or transfer of a fraction of the real estate property, together with the right to exclusive use of a part of the real estate serving housing needs. 
of clear rules for developers in their dealings with financial intermediaries and brokerage houses, often linked to banks. Such risks are also related to the absence of transparent principles determining the liability of individual entities towards the purchaser ${ }^{60}$. Industry experts effectively encourage customers to invest their savings in apart-hotels and to take out loans for this purpose.

Presently Polish legal regulations do not specify basic requirements, such as the type of the property that can be subject to short term rental in the field of condo-hotels and aparthotels ${ }^{61}$. There are no legal regulations that would grant the local governments the authority to control the risks related to such leased units. This results in the emergence of the so called "grey-zone hostels" that are not even covered by fire safety control and may pose a serious danger for the tenants and other residents of the building ${ }^{62}$. Another important issue is the frequent avoidance of taxes by owners, which leads to measurable losses to municipal budgets. Moreover, the lack of control of such premises hits the residents of the buildings where they are located, who may be exposed to disturbances and thus to the interventions of the security services. Therefore, the need for regulation in this area results primarily from the lack of control over the leased premises.

Polish law does not distinguish short-term rental from lease ${ }^{63}$. Thus, a short-term rental agreement is tantamount to a fixed-term lease agreement governed by the provisions of the Polish Civil Code and the Act on the Protection of Tenants' Rights. As there is no separate regulation concerning a short-term rental agreement, there is also no limit of the number of days for which the premises are rented and no limit of the number of premises which may be subject to such an agreement. There are no legal regulations applicable to apart-hotels and condo-hotels. At the same time, there is no clear distinction between private and business rentals.

60 Bogusława Gnela, Consumer contract in Polish civil and private international law (Warsaw: Wolters Kluwer Polska, 2013), 190 et seq.

61 Ryszard Strzelczyk, Real Estate Law (Warsaw: C.H. Beck, 2019), 415-423.

62 Act of 24.08.1991 on fire protection (iJournal of Laws 2019.1372), [Ustawa z dnia 24 sierpnia 1991 r. o ochronie przeciwpożarowej, Dz.U. 1991 no. 81 poz. 351].

${ }_{63}$ Vide: art. 659-692 of the Civil Code. Katarzyna Siwiec, Lease of commercial space and commercial premises - a review of the most important issues from the point of view of lease parties (Warsaw: C.H. Beck, 2015), 1 et seq. 
Another important issue is the problem of contradictory tax interpretations and justified concerns related to settling the income from the lease of investment apartments. Moreover, there is no certainty as to the official interpretation of the nature of premises in new hotel facilities ${ }^{64}$, which may make it impossible to divide the property into separate units and establish land and mortgage registers for them. In such a situation, individual investors would be faced with the necessity to acquire shares in the entire property instead of the separate units with their own land and mortgage register.

Moreover, despite many other risks related to short-term rental, it is worth pointing to five problem areas that are important regardless of the country or city. The first one relates to health and safety. It is a broad category that encompasses many issues such as cleanliness, parking, fire protection, and other aspects that are regulated in the hotel industry but remain unregulated in the case of short-term rentals. Another risk relates to the delineation of units designated for short-term rental. As shown above, some cities allow short-term rent without limitations, while others restrict it to designated areas and there are cities where it is entirely banned.

Another issue is the introduction of licenses in order to limit the area with short-term rentals and their number. No less important is the issue of taxation. The last issue that brings all the above elements together is the enforceability of the regulations. One thing is to introduce specific regulations and another to be able to effectively enforce them. The cities must impose restrictions that are enforceable. It also means that the limitations must be consistent with other regulations in force. What is more, they should not be excessively complicated or overly restrictive. Unenforceable provisions in the area of short-term rental are detrimental to the social and economic structure of urban residential areas.

It is worth considering the introduction of an obligation to register the premises leased to tourists and the introduction of restrictions on the rental of apartments for tourists by specifying the maximum number of days per year and the maximum number of units that can be used by one owner for short-term rental. Restrictions introduced in Berlin

64 Provincial Administrative Court in Poznań, Judgment of October 24, 2019, Ref. No. IV SA / Po 459/19, LEX No. 2736026. 
(to give just one example) allow property owners to rent only one room in an apartment where one lives.

It would also be advisable to adopt regulations setting out the obligation to ensure the safety of tourists during their stay, e.g. the information on evacuation procedure in the event of fire and compliance with basic sanitary requirements. It is also necessary to introduce regulations on liabilities of the owner of the premises towards the guests and permanent residents of the building, e.g. the owner's liability in case of his/her failure to comply with the booking agreement or penalties for the disorderly conduct of the guests.

\section{NEW INITIATIVES IN THE FIELD OF SHORT-TERM RENTAL}

The Polish Ministry of Sport and Tourism has prepared a draft of the so-called "White Paper on the regulation of the system of tourism promotion in Poland", with an aim to regulate, among other things, the system of financing tourism, as well as a range of issues related to hospitality and accommodation services, in particular the issue of short-term rental ${ }^{65}$. In the report on the preliminary consultations on this project many entities (e.g. National Association of Tourist Agents, Federation of Guide Associations, Chamber of Commerce of Polish Hotels, Pomeranian Regional Tourist Organization, Polish Tourist and Sightseeing Society (PTTK)) drew attention to the urgent need for changes. They call for the urgent changes that would pertain to all entities operating accommodation facilities, including short-term rentals, in order to liquidate inequality regarding the legal status of conventional hotels and short-term rentals.

Another important issue that emerged from pre-consultations is the need to set up a database of all establishments providing hotel services and short-term rentals as well as the need for a mandatory registration of all establishments providing accommodation services, including shortterm rentals. Attention was also drawn to the need to regulate short term

65 Report on the pre-consultation of the White Paper Regulation of the Tourist Promotion System in Poland, 2020: https://www.gov.pl/web/rozwoj/raport-z-prekonsultacji-projektu-bialej-ksiegi-regulacji-systemu-promocji-turystycznej-w-polsce. 
occasional lettings by individuals by introducing limits on the number of days per year and to exclude them from business activities as a result. The need to regulate the legal situation of a building consisting of premises intended for short-term lease, i.e. the legal status of both apart-hotels and condo-hotels, was also noted. During the pre-consultation it was also pointed out that it should be mandatory to enter the units designated for short-term rent in the 'Register of Other Facilities', which would also be accessible to the relevant authorities in the event of a need to notify the owner of an event such as flooding, technical failure, fire, intervention of the relevant services, etc. Attention was also drawn to the issue of public order violations, which should remain within the scope of responsibility of the relevant authorities, and to the fact that all establishments providing accommodation services, regardless of their type, category, or license, should be registered in the records kept by the municipality and should have their own registration number, included in every listing particularly if it is placed online.

In September 2019, the Polish Office of Competition and Consumer Protection (UOKiK) and the Polish Financial Supervision Authority (KNF) issued a warning against the risks involved in investing in apart-hotels and condo-hotels ${ }^{66}$. The UOKiK concerns were related, among other things, to the manner of financing such projects and the issue of security of such transactions. According to the provisions of the Developer's Act, the contract must be concluded in the form of a notarial deed, and the purchaser's claim is entered in the land and mortgage register. The money should be held in an escrow account. However, these provisions apply only to residential units and single-family houses. The safeguards they provide do not extend to commercial premises, exposing such investments to a particular risk. Developers do not apply the provisions of the Developer's Act to the sale of apart-hotels and hence, in the event of a collapse of the project and unfinished construction the investors may suffer a huge loss.

In the light of the above it is necessary that potential investors exercise caution and thoroughly analyze the project and potential risks. The oper-

66 More information: September, 2020: https://www.uokik.gov.pl/aktualnosci. php?news_id=15799. 
ations of apart-hotels and condo-hotels are largely seasonal, which means that the returns are far from guaranteed. What is more, the costs related to servicing the facility, the debt, or tax obligations must also be taken into account. Short-term rental is at the moment largely unregulated in respect of the construction process, protection of the purchasers, tax issues and various issues related to tourism and the protection of tenants.

\section{IMPORTANCE OF THE CJEU JUDGMENT \\ OF SEPTEMBER 22, 2020, C-724/18}

On 22 September 2020 the European Court of Justice issued a judgment C-724/18 that is of great significance for short-term rental, holding that the EU states have the right to limit short-term rent ${ }^{67}$. The judgment was a result of the prejudicial question filed by Cour de cassation (French cassation court). Cali Apartments and HX each own a studio apartment Paris. The municipal police established that they offered the apartments for short-term rental without a relevant permit. Tribunal de grande instance de Paris with which procureur de la République (the Prosecutor for the Republic) filed the application for interim relief under Article L. 631-7 of the French Construction and Housing Code ${ }^{68}$ ordered Cali Apartments and $H X$ to pay a fine of 5,000 Euros and 15,000 Euros respectively and ordered that the use of the properties in question be changed back to residential.

Cour d'appel de Paris (the court of appeal) held that the judgment was final. Cali Apartments and HX filed cassation appeal with the Cour de cas-

${ }^{67}$ Judgment of the Court (Grand Chamber) of 22 September 2020 (requests for a preliminary ruling from the Cour de cassation - France) - Cali Apartments SCI (C-724/18) and HX (C-727/18) v Procureur général près la cour d'appel de Paris and Ville de Paris (Joined Cases C-724/18 and C-727/18), OJ C 35, 28.1.2019. http://curia.europa. eu/juris/document/document.jsf?text $=\&$ docid=233725\&pageIndex $=0$ \&doclang=EN\&mode $=$ req $\&$ dir $=\&$ occ $=$ first $\&$ part $=1 \&$ cid $=17108522$.

${ }^{68}$ According to this regulation, the declaration to restore the premises to its previous condition, as provided for in the second paragraph of Article L 631-7-1, is made by the owner of the premises or his representative, or by the person presenting proof of possession entitling to restore the premises to its previous use. 
sation (cassation court), claiming that the judgments were issued in violation of the principle of the priority of the EU law ${ }^{69}$. The parties claimed in their appeal that the judgments failed to demonstrate that the restriction of freedom of services resulting from the national regulations is justified by overriding reasons in general interest ${ }^{70}$ and that it has not been demonstrated that the objective pursued may not be achieved by less restrictive measures. Furthermore, the appellants held that the restriction in the form of the obligation to have a relevant license does not meet the criteria falling from the requirements of Directive 2006/123/EC ${ }^{71}$.

The European Court of Justice ruled that 'the authorization scheme' to rent out apartments to tourists does not violate the principle of the free movement of services. The ECJ held that prevention of shortages of housing for long-term rental represents a primary general interest which justifies such regulation. It means that the primary aim of the regulation is to establish the mechanism to prevent the shortage of housing for long-term rental and increasing tension on real estate markets, which constitutes an overriding reason in the public interest. On the other hand, the relevant French regulations are proportionate to the objective pursued as they are limited to the specific activity i.e. renting out the property. What is more, the ECJ held that the objective could not be achieved by less restrictive measure.

\section{CONCLUSIONS}

Although the market of condo-hotels and apart-hotels is still relatively young, it will probably continue to develop quickly. Its diversity results in great uncertainty as to the applicable provisions of law in this area. It is therefore necessary to introduce uniform regulations in order to ensure

69 Stanisław Biernat, "Zasada pierwszeństwa prawa unijnego po Traktacie z Lizbony," Gdańskie Studia Prawnicze, vol. XXV (2011): 47-61.

70 Vide: art. 9 directive 2006/123/WE of the European Parliament and of the Council of 12 December 2006 on services in the internal market, OJ L 376, 27.12.2006, p. 36-68.

71 Vassilis Hatzopoulos and Sofia Roma, "Caring for sharing? The collaborative economy under EU law," Common Market Law Review, vol. 57, no. 1 (2017): 100. 
better protection of the rights of the contracting parties ${ }^{72}$. It also seems justified to change the regulations pertaining to housing communities (the Act on the Ownership of Premises) by granting them the power to decide by a resolution whether or not they consent to short-term rentals ${ }^{73}$ in condo and aparthotels. Under the current laws, the courts revoke the resolutions prohibiting short-term rental on the grounds that such resolutions excessively restrict ownership rights. It cannot be assumed that negative phenomena will take place and only when they do occur can legal measures be taken to counter them. However, the issue of housing communities goes far beyond the scope of this article.

The regulations in force do not allow to impose higher fees on the owners of short-term rentals as the relevant regulations of the Act on Ownership apply only to commercial premises and they do not cover the premises registered as units for residential purposes even if they are actually leased with a commercial purpose. Another important reason why short-term rental in condo-hotels and apart-hotels should be regulated is, last but not least, the need to prevent the gentrification of cities and the need to introduce controls over the quantity and quality of the apartments used for rental purposes.

To sum up, despite various advantages, short-term rental of apartments can be a dangerous phenomenon. Landlords often lack protection also due to the absence of relevant insurance. They are exposed to risks related to their business activity and fail to address them. Tenants and neighbors are exposed to noise and other disturbances. Frequently, they also have to make extra payments or pay increased rent. In the face of the absence of relevant regulations, it is necessary to adopt a comprehensive approach related to short-term rental.

Considering the above and the judgment of the ECJ, I believe that the responsibility to examine if a given "authorization system" addresses the shortage of apartments for long-term rental. Another issue that

72 The owners have the right to appeal against an unfavorable resolution of the housing community on the grounds of its non-compliance with the law or the agreement of the owners of the premises or if it violates the principles of proper management of the common property or otherwise violates his/her interests.

73 E.g. Court of Appeal in Łódź, Judgment of 10 February 2017, Ref. No. ACa 961/16, LEX. 
should be taken into account is the profitability of commercial shortterm rental compared to long-term rental. It should also be established if the obligation of compensation can be met in a given area based on reasonable and transparent market conditions. In the light of the above it must be stated that preventing shortages of property for long-term rental constitutes an important public interest and provides sufficient grounds for state intervention. It is worth remembering that neither freedom of business activity nor ownership rights are absolute and as such they may be subject to certain limitations ${ }^{74}$. Member States may establish certain "authorization system" for short-term rental operators on condition that the system is non-discriminatory and justified by overriding reasons in the general interest.

However, the introduction of restrictions cannot be arbitrary, as it must be justified and comply with the principle of proportionality of the measures taken to the protected interest. The ECJ judgment is paving the way for the Polish legislator to regulate short-term rental in order to ensure fair competition, protection of the recipients of services, and by the same token limit risks related to investing in short-term rentals. The postulated solution is to adopt relevant legal regulations on the local and national level, which would reduce the risk related to investing in short-term rentals and have a positive impact on further development of this institution.

\section{REFERENCES}

Armstrong, George M. jr. "Louisiana Condominium Law and the Civilian Tradition." Louisiana Law Review 46, no. 1 (1985): 65-86.

Asslund, Anders. The Last Shall Be the First: The East European Financial Crisis.

Washington, Dc: Peterson Institute for International Economics, 2010.

Barron, Kelly, Edward Kung, and Davide Proserpio. The Effect of Home-Sharing on House Prices and Rents: Evidence from Airbnb. 2020.

Biernat, Stanisław. "Zasada pierwszeństwa prawa unijnego po Traktacie z Lizbony." Gdańskie Studia Prawnicze, vol. XXV (2011): 47-61.

74 Under the applicable provisions of Polish law, there are also restrictions on the possibility of using premises intended for residential purposes for other (commercial) purposes. 
Dübel, Hans Joachim, Władysław Jan Brzeski, and Ellen Hamilton. Rental Choice and Housing Policy Realignment in Transition: Post-Privatization Challenges in the Europe and Central Asia Region, Policy Research Working Paper, World Bank, no. 3884 (2006).

Bucholc-Srogosz, Katarzyna. "Condohotels on the Polish real estate market." Scientific Notebooks of the AJD Administration Institute in Czestochowa 2, no. 14 (2016): 241-249.

Busch, Christoph. "Regulating Airbnb in Germany - status quo and future trends." Journal of European Consumer and Market Law, vol. 8, no. 1 (2019): 39-41.

Chrabąszcz, Karolina. "Condoinvestments as an alternative form of capital allocation." Scientific Papers of the Matopolska University of Economics in Tarnów 24, no. 1 (2014): 47-58.

Dredge, Dianne. "The impact of regulatory approaches targeting collaborative economy in the tourism accommodation sector." Impulse paper, no. 9 Aalborg University (2016): 3-88.

Downey, James F. "The Aparthotel: A Useful Tool for Investors and Developers." Cornell Hotel and Restaurant Administration Quarterly, no. 32 (1991): 53-55. Garcia-López, Miquel-Àngel, Jordi Jofre-Monseny, Rodrigo Martínez Mazza, and Mariona Segú. "Do short-term rental platforms affect housing Markets? Evidence from AirBnb in Barcelona." IEB Working Paper no. 2019/05, Institut d'Economia de Barcelona, 2019.

Gnela, Bogusława. Consumer contract in Polish civil and private international law. Warsaw: Wolters Kluwer Polska, 2013.

Hatzopoulos, Vassilis, and Roma Sofia. "Caring for sharing? The collaborative economy under EU law." Common Market Law Review, vol. 57, no. 1 (2017): 81-121.

Kaźmierczyk, Aneta. Common property of premises owners. Legal and substantive issues. Warsaw: C.H. Beck, 2015.

Kaźmierczyk, Aneta. "Issues of short-term rental in light of EU and member states regulations." PWPM - Review of International, European and Comparative Law, vol. XVII (2019): 180-198.

Kaźmierczyk, Aneta. "Certificate of independence of premises." Rejent, no. 1 (2013): 11-38.

Peppercorn, Ira Gary, and Claude Taffin. Rental Housing. Lessons from International Experience and Policies for Emerging Markets. Washington, Dc: The World Bank, 2013.

Siwiec, Katarzyna. Lease of commercial space and commercial premises - a review of the most important issues from the point of view of lease parties. Warsaw: C.H. Beck, 2015.

Strzelczyk, Ryszard. Real Estate Law. Warsaw: C.H. Beck, 2019. 
Taylor, Robyn. "Why Condo Hotels are a Hot Concept." National Real Estate Investor (2005).

Van Der Merwe, Cornelius. European Condominium Law. Cambridge: Cambridge University Press, 2015.

Zaradkiewicz, Kamil. "Timesharing - a special relation of property law." In Private law system vol. 4, Property law, edited by Edward Gniewek, 165-180. Warsaw: C.H. Beck, 2012. 
